\title{
Erratum to: Is RAF1 protein from Synechocystis sp. PCC 6803 really needed in the cyanobacterial Rubisco assembly process?
}

\author{
Piotr Kolesinski $^{1} \cdot$ Malgorzata Rydzy $^{1}$ - Andrzej Szczepaniak ${ }^{1}$
}

Published online: 8 February 2017

(C) The Author(s) 2017

\section{Erratum to: Photosynth Res \\ DOI 10.1007/s11120-017-0336-4}

Unfortunately, the articles by Klotz et al. (2016) and Cheregi et al. (2016) cited in the Discussion section of the original article were not included in the References section. The details are printed below.

\section{References}

Cheregi O, Wagner R, Funk C (2016) Insights into the cyanobacterial Deg/HtrA proteases. Front Plant Sci 7:694

Klotz A, Georg J, Bučinská L, Watanabe S, Reimann V, Januszewski W, Sobotka R, Jendrossek D, Hess WR, Forchhammer K (2016) Awakening of a dormant cyanobacterium from nitrogen chlorosis reveals a genetically determined program. Curr Biol 26(21):2862-2872 